\title{
Effect of Integrated Nutrient Management on Growth Parameters of Coriander (Coriandrum sativum L.) Cultivars under Telangana Conditions
}

\author{
P. Suman*, D. Lakshminarayana, P. Prasanth and D. Saida Naik
}

Department of Plantation, Spices, Medicinal and Aromatic crops, College of Horticulture, Sri

Konda Laxman Telangana State Horticultural University, Rajendranagar-500 030, Hyderabad, India

*Corresponding author

\section{Keywords}

Azospirillum, PSB, FYM, Vermicompost, RDF, $\mathrm{AD}-1$ and Suguna

Article Info

Accepted:

22 October 2018

Available Online:

10 November 2018

\section{A B S T R A C T}

A field experiment was conducted during rabi 2017-18 at PG block, College of Horticulture, Sri Konda Laxman Telangana State Horticultural University, Hyderabad, Telangana, India, to study the effect of integrated nutrient management on growth parameters of coriander (Coriandrum sativum L.) cultivars. The experiment was evaluated in randomized block design with factorial concept consists two factors like Cultivars and Inorganic, Organic and Bio fertilizers. The first factor comprised of two cultivars i.e. AD-1 and Suguna besides the second factor consists fertilizer levels of $\mathrm{F}_{1}-100 \%$ RDF (15-40-20 NPK Kg ha $\left.{ }^{-1}\right), F_{2}-75 \%$ RDF + Farmyard Manure (FYM @ $\left.10 \mathrm{t} \mathrm{ha}^{-1}\right)+$ Azospirillum and PSB ( $5 \mathrm{~g} \mathrm{Kg}^{-1}$ of seed as seed inoculation $+5 \mathrm{Kg} \mathrm{ha}^{-1}$ as soil application). $\mathrm{F}_{3}-75 \% \mathrm{RDF}+$ Vermicompost (VC @ 5t ha $\left.{ }^{-1}\right)+$ Azospirillum and PSB $\left(5 \mathrm{~g} \mathrm{Kg}^{-1}\right.$ of seed as seed inoculation $+5 \mathrm{Kg} \mathrm{ha}^{-1}$ as soil application), $\mathrm{F}_{4}-50 \% \mathrm{RDF}+$ Farmyard Manure (FYM @ $\left.10 \mathrm{t} \mathrm{ha}^{-1}\right)+$ Azospirillum and PSB $\left(5 \mathrm{~g} \mathrm{Kg}^{-1}\right.$ of seed as seed inoculation $+5 \mathrm{Kg} \mathrm{ha}^{-1}$ as soil application), $\mathrm{F}_{5}-50 \% \mathrm{RDF}+$ Vermicompost $\left(\mathrm{VC} @ 5 \mathrm{t} \mathrm{ha}^{-1}\right)+$ Azospirillum and PSB $\left(5 \mathrm{~g} \mathrm{Kg}^{-1}\right.$ of seed as seed inoculation $+5 \mathrm{Kg} \mathrm{ha}^{-1}$ as soil application). Ten treatment combinations were replicated thrice. Among the treatments, $\mathrm{F}_{3}-75 \% \mathrm{RDF}+$ Vermicompost @ $5 \mathrm{t} \mathrm{ha}^{-1}+$ Azospirillum and PSB $\left(5 \mathrm{~g} \mathrm{Kg}^{-1}\right.$ of seed as seed inoculation $+5 \mathrm{Kg} \mathrm{ha}^{-1}$ as soil application) with the variety $\mathrm{V}_{2}$-Suguna recorded least number of days taken to 50 per cent and 100 per cent seed germination and maximum plant height, number of secondary branches per plant, leaf area, minimum number of days taken to first and 50 per cent flowering, number of umbels per plant and umbellate per umbel.

\section{Introduction}

Coriander (Coriandrum sativum L.) is an annual herbaceous plant locally known as Dhania belongs to the family Apiaceae and is native to the Mediterranean region. The name was derived from the Greek word 'koris' and was given on accounts of its unpleasant odour of unripe green fruits. Coriander is extensively grown in Bangladesh, India, Russia, Central Europe and Morocco and it has been cultivated since human antiquity (Bhuiyan et al., 2009). India is the biggest producer, consumer and exporter of coriander in the world and is mainly grown in Rajasthan, Gujarat, Andhra Pradesh, Madhya Pradesh, 
Tamil Nadu, Orissa, Karnataka and Telangana.

In India coriander is cultivated in an area of 6.74 lakh ha with a production of 8.83 lakh MT, where as in Telangana, the area and production are 10,000 ha and 400 MT respectively (National Horticulture Board, 2016).

In recent years, bio fertilizers have emerged as an important component of integrated nutrient supply system and have shown promise to improve crop yields and nutrient supplies. Azotobacter, PSB and Azospirillum are the most wide spread bio fertilizers significantly contributing $\mathrm{N}, \mathrm{P}$ and $\mathrm{K}$ to plants and also providing resistance to drought situation (Maheshwari et al., 1991).

The application of nutrients through various sources is newer approach and being advocated for sustainable production. The integrated nutrient management has a crucial role in improving the plant physiology characters that builds levels of resistance and reduces the incidence of disease and pest attacks (Mirchandani and Mirchandani, 2005). Nitrogen fixing bacteria like Azospirillum have a great potential to reduce the nitrogenous fertilizer requirements whereas, Phosphorus solubilising bacteria is known to make the soil fixed phosphorus in to readily available form, subsequently increased the productivity of the crops.

\section{Materials and Methods}

Present field experiment was conducted during rabi 2017-18 at PG block, College of Horticulture, Sri Konda Laxman Telangana State Horticultural University, Hyderabad, Telangana, India.

The experiment was carried out with two varieties i.e. AD-1 and Suguna with five fertilizer levels i.e. 100\% RDF (15-40-20 NPK $\left.\mathrm{Kg} \mathrm{ha}{ }^{-1}\right), 75 \%$ RDF + Farmyard Manure $\left(\right.$ FYM @ $\left.10 \mathrm{t} \mathrm{ha}^{-1}\right)+$ Azospirillum and PSB (5g $\mathrm{Kg}^{-1}$ of seed as seed inoculation $+5 \mathrm{Kg} \mathrm{ha}^{-1}$ as soil application), 75\% RDF + Vermicompost (VC@ @ $\left.\mathrm{tha}^{-1}\right)+$ Azospirillum and PSB (5g $\mathrm{Kg}^{-1}$ of seed as seed inoculation $+5 \mathrm{Kg} \mathrm{ha}^{-1}$ as soil application), $50 \%$ RDF + Farmyard Manure (FYM @10 t ha $\left.{ }^{-1}\right)+$ Azospirillum and PSB $\left(5 \mathrm{~g} \mathrm{Kg}^{-1}\right.$ of seed as seed inoculation +5 $\mathrm{Kg} \mathrm{ha}^{-1}$ as soil application), $50 \% \mathrm{RDF}+$ Vermicompost (VC@ @ $\mathrm{t} \mathrm{ha}^{-1}$ ) + Azospirillum and PSB $\left(5 \mathrm{~g} \mathrm{Kg}^{-1}\right.$ of seed as seed inoculation $+5 \mathrm{Kg} \mathrm{ha}^{-1}$ as soil application) in a Factorial Randomized Block Design and replicated thrice. Seeds were sown in the plot of $2 \mathrm{~m} \times$ $1.5 \mathrm{~m}$ at spacing of $30 \mathrm{~cm} \times 10 \mathrm{~cm}$.

The recommended dosages of N, P and K @ 15:40:20 kg ha ${ }^{-1}$ were applied in the form of urea, single super phosphate and muriate of potash respectively. Urea was applied in the three splits, the first as basal application and the other two doses at 25 and 50 days after sowing. The entire dose of single super phosphate and muriate of potash were applied at the time of sowing as basal dose. The vermicompost and the farmyard Manure were incorporated in to respective plots just prior to sowing of seed and then slightly covered with the fine soil.

Slurry of $200 \mathrm{~g}$ of each of Azospirillum and Phosphorous Solubilising Bacteria were dissolved in $1000 \mathrm{ml}$ of jaggery solution (100 $\mathrm{g}$ of jaggery in $1000 \mathrm{ml}$ of water) separately and combination of both $100 \mathrm{~g}$ Azospirillum and $100 \mathrm{~g}$ Phosphorous Solubilising Bacteria were dissolved in $1000 \mathrm{ml}$ of jaggery solution. The coriander seeds were dipped in the slurry for about 30 minutes before sowing. Need based cultural and plant protection operations were taken up to the seed harvest. Five plant samples from each replication were selected at random to record data on growth characters. The experimental data was analysed 
statistically by the method of analysis of variance as out lined by Panse and Sukhatme (1985).

\section{Results and Discussion}

\section{Growth parameters}

Growth parameters such as plant height, number of secondary branches per plant and leaf area showed a significant difference between fertilizer levels and varieties at 60,90 days and at harvest stage.

Among the treatments, $\mathrm{F}_{3}-75 \%$ RDF + Vermicompost@5t ha ${ }^{-1}+$ Azospirillum and PSB $\left(5 \mathrm{~g} \mathrm{Kg}^{-1}\right.$ of seed as seed inoculation +5 $\mathrm{Kg} \mathrm{ha}^{-1}$ as soil application) with the variety $\mathrm{V}_{2}$-Suguna recorded higher plant height $(97.67$ $\mathrm{cm}$ ) (Table 1), number of secondary branches per plant (18.30) (Table 2) and maximum leaf area $\left(79.73 \mathrm{~cm}^{2}\right)$ (Table 3) at harvest stage.

It was due to the seed treatment with Azospirillum and Phosphorous solubilising bacteria enhanced the nitrogen and other nutrients availability, resulted in increased vegetative growth (Mounika et al., 2018). Similar results were also reported by Sahu et al., (2014), Tripathi et al., (2013) and Hnamte et al., (2013) in coriander who stated that synergistic effect of inorganic and organic fertilizer increased plant height.

Integrated application of bio fertilizers with inorganic fertilizers have increased plant height by enhancing the nitrogen content and the rate of photosynthesis which is in agreement with (Migahed et al., 2004; Choudhary et al., 2004).

More number of secondary branches per plant was due to higher plant height, subsequently more photosynthates, led to production of more number of secondary branches per plant. The present investigation was in consistent with other reports of Sahu et al., (2014) in coriander, who stated that more number of secondary branches per plant was due to treatment supplied with bio-fertilizers and organic manures.

Maximum leaf area was due to the balanced fertilizer application increased leaf area which might be due to the availability of all nutrients in the rhizosphere (Priyadarshini et al., 2017). Similar results reported by Nagar et al., (2009) in coriander, who reported that available nutrients favoured better growth and development of the crop.

\section{Flowering parameters}

Flowering parameters such as number of days taken to first and 50 per cent flowering, number of umbels per plant and umbellate per umbel showed a significant difference between fertilizer levels and varieties. Among the treatments, $\mathrm{F}_{3}-75 \% \mathrm{RDF}+$ Vermicompost @ 5 $\mathrm{tha}^{-1}+$ Azospirillum and PSB $\left(5 \mathrm{~g} \mathrm{Kg}^{-1}\right.$ of seed as seed inoculation $+5 \mathrm{Kg} \mathrm{ha}^{-1}$ as soil application) with the variety $\mathrm{V}_{2}$-Suguna recorded minimum number of days taken to first flowering (39.00 days) and 50 per cent flowering (47.30 days) (Table 4). Similarly the same treatment recorded maximum number of umbels per plant (37.50) and umbellate per umbel (8.53) (Table 5).

Least number of days taken to first flowering and 50 per cent flowering might be due that bio fertilizer treated plants became physiologically more active and enable to synthesize required amounts of hormones. The results are comparable with that of Hnamte $e t$ al., (2013).

Maximum number of umbels per plant might be due to luxuriant vegetative growth, more number of branches per plant, broader leaf area and least number of days taken to 50 per cent flowering. 
Table.1 Effect of integrated nutrient management on plant height $(\mathrm{cm})$ in coriander cultivars at different growth stages

\begin{tabular}{|c|c|c|c|c|c|c|c|c|c|c|c|c|}
\hline Fertilizers / & \multicolumn{12}{|c|}{ Plant Height (cm) } \\
\hline \multirow{2}{*}{ Treatments(F) } & \multicolumn{3}{|c|}{$30 \mathrm{DAS}$} & \multicolumn{3}{|c|}{60 DAS } & \multicolumn{3}{|c|}{$90 \mathrm{DAS}$} & \multicolumn{3}{|c|}{ At Harvest stage } \\
\hline & $\mathrm{V}_{1}$ & $\mathrm{~V}_{2}$ & Mean & $\mathrm{V}_{1}$ & $\mathrm{~V}_{2}$ & Mean & $\mathrm{V}_{1}$ & $\mathrm{~V}_{2}$ & Mean & $\mathrm{V}_{1}$ & $\mathrm{~V}_{2}$ & Mean \\
\hline$\overline{F_{1}}$ & 8.40 & 9.80 & $9.10^{\mathrm{d}}$ & 39.40 & 40.33 & $39.87^{e}$ & 69.50 & 70.20 & $69.85^{\mathrm{e}}$ & 72.50 & 73.13 & $72.82^{e}$ \\
\hline $\mathbf{F}_{2}$ & 11.77 & 13.07 & $12.42^{\mathrm{ab}}$ & 49.00 & 54.33 & $51.67^{b}$ & 85.33 & 91.33 & $88.33^{b}$ & 88.33 & 94.33 & $91.33^{b}$ \\
\hline $\mathbf{F}_{3}$ & 12.70 & 13.17 & $12.93^{\mathrm{a}}$ & 52.00 & 56.50 & $54.25^{\mathrm{a}}$ & 88.17 & 94.67 & $91.42^{\mathrm{a}}$ & 91.17 & 97.67 & $94.42^{a}$ \\
\hline $\mathrm{F}_{4}$ & 10.43 & 11.10 & $10.77^{\mathrm{c}}$ & 42.00 & 46.40 & $44.20^{\mathrm{d}}$ & 73.33 & 79.60 & $76.47^{\mathrm{d}}$ & 76.33 & 82.60 & $79.47^{\mathrm{d}}$ \\
\hline$F_{5}$ & 10.90 & 11.63 & $11.27^{\mathrm{bc}}$ & 44.00 & 48.70 & $46.35^{c}$ & 76.00 & 82.83 & $79.42^{c}$ & 79.00 & 85.83 & $82.42^{c}$ \\
\hline \multirow[t]{2}{*}{ Mean } & 10.84 & 11.75 & & $45.28^{b}$ & $49.25^{\mathrm{a}}$ & & $78.47^{b}$ & $83.73^{\mathrm{a}}$ & & $81.47^{b}$ & $86.71^{\mathrm{sa}}$ & \\
\hline & $\mathrm{SEm} \pm$ & $\mathrm{CD}$ at $5 \%$ & & $\mathrm{SEm} \pm$ & $\mathrm{CD}$ at $5 \%$ & & $\mathrm{SEm} \pm$ & $\mathrm{CD}$ at $5 \%$ & & $\mathrm{SEm} \pm$ & $\mathrm{CD}$ at $5 \%$ & \\
\hline Fertilizers(F) & 0.49 & 1.46 & & 0.51 & 1.51 & & 0.75 & 2.21 & & 0.75 & 2.23 & \\
\hline Varieties(V) & 0.31 & NS & & 0.32 & 0.95 & & 0.47 & 1.40 & & 0.47 & 1.41 & \\
\hline$(\mathrm{V} \times \mathrm{F})$ & 0.69 & NS & & 0.72 & 2.13 & & 1.05 & 3.13 & & 1.06 & 3.15 & \\
\hline
\end{tabular}

Table.2 Effect of integrated nutrient management on number of secondary branches per plant in coriander cultivars at Different growth stages

\begin{tabular}{|c|c|c|c|c|c|c|c|c|c|c|c|c|}
\hline \multirow{3}{*}{$\begin{array}{c}\text { Fertilizers / } \\
\text { Treatments(F) }\end{array}$} & \multicolumn{12}{|c|}{ Number of secondary branches per plant } \\
\hline & \multicolumn{3}{|c|}{$30 \mathrm{DAS}$} & \multicolumn{3}{|c|}{$60 \mathrm{DAS}$} & \multicolumn{3}{|c|}{90 DAS } & \multicolumn{3}{|c|}{ At Harvest stage } \\
\hline & $\mathrm{V}_{1}$ & $\mathrm{~V}_{2}$ & Mean & $\mathrm{V}_{1}$ & $\mathrm{~V}_{2}$ & Mean & $\mathrm{V}_{1}$ & $\mathrm{~V}_{2}$ & Mean & $\mathrm{V}_{1}$ & $\mathrm{~V}_{2}$ & Mean \\
\hline$\overline{F_{1}}$ & 4.37 & 4.40 & $4.38^{d}$ & 8.00 & 8.50 & $8.25^{\mathrm{d}}$ & 10.10 & 10.50 & $10.30^{d}$ & 12.00 & 12.50 & $12.25^{\mathrm{e}}$ \\
\hline $\mathbf{F}_{2}$ & 5.00 & 5.20 & $5.10^{\mathrm{ab}}$ & 10.40 & 12.30 & $11.35^{b}$ & 12.40 & 14.30 & $13.35^{b}$ & 14.40 & 16.30 & $15.35^{\mathrm{b}}$ \\
\hline$\overline{F_{3}}$ & 5.13 & 5.30 & $5.22^{\mathrm{a}}$ & 11.20 & 14.30 & $12.75^{\mathrm{a}}$ & 13.20 & 16.30 & $14.75^{\mathrm{a}}$ & 15.20 & 18.30 & $16.75^{\mathrm{a}}$ \\
\hline$\overline{F_{4}}$ & 4.53 & 4.70 & $4.62^{c}$ & 8.80 & 9.40 & $9.10^{\mathrm{cd}}$ & 10.80 & 11.40 & $11.10^{\mathrm{cd}}$ & 12.80 & 13.40 & $13.10^{\mathrm{cd}}$ \\
\hline$F_{5}$ & 4.67 & 4.80 & $4.73^{b c}$ & 9.10 & 9.70 & $9.40^{c}$ & 11.10 & 11.70 & $11.40^{c}$ & 13.10 & 13.70 & $13.40^{c}$ \\
\hline \multirow[t]{2}{*}{ Mean } & 4.74 & 4.88 & & $9.50^{b}$ & $10.84^{\mathrm{a}}$ & & $11.52^{b}$ & $12.84^{\mathrm{a}}$ & & $13.50^{b}$ & $14.84^{\mathrm{a}}$ & \\
\hline & $\mathrm{SEm} \pm$ & $\mathrm{CD}$ at $5 \%$ & & $\mathrm{SEm} \pm$ & $\mathrm{CD}$ at $5 \%$ & & $\mathrm{SEm} \pm$ & $\mathrm{CD}$ at $5 \%$ & & $\mathrm{SEm} \pm$ & $\mathrm{CD}$ at $5 \%$ & \\
\hline Fertilizers(F) & 0.08 & 0.23 & & 0.33 & 0.98 & & 0.28 & 0.84 & & 0.26 & 0.76 & \\
\hline Varieties(V) & 0.05 & NS & & 0.21 & 0.62 & & 0.18 & 0.53 & & 0.16 & 0.48 & \\
\hline$(\mathrm{V} \times \mathrm{F})$ & 0.11 & NS & & 0.47 & 1.39 & & 0.40 & 1.19 & & 0.36 & 1.08 & \\
\hline
\end{tabular}


Table.3 Effect of integrated nutrient management on leaf area $\left(\mathrm{cm}^{2}\right)$ in coriander cultivars at different growth stages

\begin{tabular}{|c|c|c|c|c|c|c|c|c|c|c|c|c|}
\hline Fertilizers / & \multicolumn{12}{|c|}{ Leaf Area $\left(\mathrm{cm}^{2}\right)$} \\
\hline \multirow[t]{2}{*}{ Treatments(F) } & \multicolumn{3}{|c|}{$30 \mathrm{DAS}$} & \multicolumn{3}{|c|}{60 DAS } & \multicolumn{3}{|c|}{90 DAS } & \multicolumn{3}{|c|}{ At Harvest stage } \\
\hline & $\mathrm{V}_{1}$ & $\mathrm{~V}_{2}$ & Mean & $\mathrm{V}_{1}$ & $\mathrm{~V}_{2}$ & Mean & $\mathrm{V}_{1}$ & $\mathrm{~V}_{2}$ & Mean & $\mathrm{V}_{1}$ & $\mathrm{~V}_{2}$ & Mean \\
\hline$F_{1}$ & 26.37 & 27.37 & $26.87^{\mathrm{e}}$ & 61.40 & 62.40 & $61.90^{\mathrm{e}}$ & 64.50 & 65.40 & $64.95^{\mathrm{e}}$ & 65.50 & 66.80 & $66.15^{\mathrm{e}}$ \\
\hline $\mathbf{F}_{2}$ & 31.39 & 32.40 & $31.90^{\mathrm{ab}}$ & 67.50 & 70.80 & $69.15^{b}$ & 70.54 & 74.91 & $72.73^{b}$ & 71.25 & 76.91 & $74.08^{b}$ \\
\hline $\mathrm{F}_{3}$ & 32.13 & 33.33 & $32.73^{a}$ & 68.80 & 73.70 & $71.25^{\mathrm{a}}$ & 72.57 & 77.73 & $75.15^{\mathrm{a}}$ & 73.60 & 79.73 & $76.67^{\mathrm{a}}$ \\
\hline $\mathbf{F}_{4}$ & 28.80 & 30.05 & $29.43^{\mathrm{cd}}$ & 63.30 & 65.40 & $64.35^{\mathrm{d}}$ & 66.90 & 68.53 & $67.72^{\text {cd }}$ & 67.40 & 69.60 & $68.50^{\text {cd }}$ \\
\hline$F_{5}$ & 29.74 & 30.40 & $30.07^{\mathrm{c}}$ & 64.50 & 66.90 & $65.70^{c}$ & 67.50 & 69.43 & $68.47^{c}$ & 68.50 & 70.10 & $69.30^{c}$ \\
\hline Mean & 29.69 & 30.71 & & $65.10^{\mathrm{b}}$ & $67.84^{\mathrm{a}}$ & & $68.40^{\mathrm{b}}$ & $71.20^{\mathrm{a}}$ & & $69.25^{b}$ & $72.63^{\mathrm{a}}$ & \\
\hline & $\mathrm{SEm} \pm$ & $\mathrm{CD}$ at $5 \%$ & & SEm \pm & $\mathrm{CD}$ at $5 \%$ & & $\mathrm{SEm} \pm$ & $\mathrm{CD}$ at $5 \%$ & & $\mathrm{SEm} \pm$ & $\mathrm{CD}$ at $5 \%$ & \\
\hline Fertilizers(F) & 0.55 & 1.63 & & 0.42 & 1.25 & & 0.43 & 1.27 & & 0.58 & 1.72 & \\
\hline Varieties(V) & 0.35 & NS & & 0.27 & 0.79 & & 0.27 & 0.80 & & 0.37 & 1.09 & \\
\hline$(\mathrm{V} \times \mathrm{F})$ & 0.77 & NS & & 0.60 & 1.77 & & 0.60 & 1.79 & & 0.82 & 2.43 & \\
\hline
\end{tabular}

Table.4 Effect of integrated nutrient management on days taken to first and 50 per cent flowering in coriander cultivars

\begin{tabular}{|c|c|c|c|c|c|c|}
\hline \multirow{2}{*}{$\begin{array}{c}\text { Fertilizers / } \\
\text { Treatments(F) }\end{array}$} & \multicolumn{3}{|c|}{ Days taken to first flowering } & \multicolumn{3}{c|}{ Days taken to 50 per cent flowering } \\
\hline & $\mathrm{V}_{1}$ & $\mathrm{~V}_{2}$ & Mean & $\mathrm{V}_{1}$ & $\mathrm{~V}_{2}$ \\
\hline $\mathrm{F}_{1}$ & 50.00 & 49.80 & $49.90^{\mathrm{e}}$ & 58.20 & 57.30 & $57.75^{\mathrm{e}}$ \\
\hline $\mathrm{F}_{2}$ & 44.27 & 42.00 & $43.13^{\mathrm{b}}$ & 52.60 & 50.57 & $51.58^{\mathrm{b}}$ \\
\hline $\mathrm{F}_{3}$ & 43.00 & 39.00 & $41.00^{\mathrm{a}}$ & 52.00 & 47.30 & $49.65^{\mathrm{a}}$ \\
\hline $\mathrm{F}_{4}$ & 48.30 & 46.97 & $47.63^{\mathrm{cd}}$ & 56.30 & 54.10 & $55.20^{\text {cd }}$ \\
\hline $\mathrm{F}_{5}$ & 47.30 & 45.90 & $46.60^{\mathrm{c}}$ & 55.30 & 53.47 & $54.38^{\mathrm{c}}$ \\
\hline Mean & $46.57^{\mathrm{b}}$ & $44.73^{\mathrm{a}}$ & & $54.88^{\mathrm{b}}$ & $52.55^{\mathrm{a}}$ & \\
\hline & $\mathrm{SEm} \pm$ & $\mathrm{CD}$ at $5 \%$ & & $\mathrm{SEm} \pm$ & $\mathrm{CD}^{\mathrm{at}} 5 \%$ \\
\hline Fertilizers(F) & 0.41 & 1.22 & & 0.40 & 1.18 \\
\hline
\end{tabular}




\section{Int.J.Curr.Microbiol.App.Sci (2018) 7(11): 2871-2877}

Table.5 Effect of integrated nutrient management on number of umbels per plant and umbellate per umbel in coriander cultivars

\begin{tabular}{|c|c|c|c|c|c|c|}
\hline \multirow{2}{*}{$\begin{array}{c}\text { Fertilizers / } \\
\text { Treatments(F) }\end{array}$} & \multicolumn{3}{|c|}{ Number of umbels per plant } & \multicolumn{3}{|c|}{ Number of umbellate per umbel } \\
\hline & $\mathrm{V}_{1}$ & $\mathrm{~V}_{2}$ & Mean & $\mathrm{V}_{1}$ & $\mathrm{~V}_{2}$ & Mean \\
\hline $\mathbf{F}_{1}$ & 25.80 & 26.30 & $26.05^{\mathrm{e}}$ & 6.85 & 7.06 & $6.96^{\mathrm{e}}$ \\
\hline $\mathbf{F}_{2}$ & 31.60 & 34.40 & $33.00^{b}$ & 7.74 & 8.28 & $8.01^{b}$ \\
\hline $\mathbf{F}_{3}$ & 32.20 & 37.50 & $34.85^{\mathrm{a}}$ & 7.97 & 8.53 & $8.25^{\mathrm{a}}$ \\
\hline $\mathbf{F}_{4}$ & 27.30 & 29.20 & $28.25^{\mathrm{cd}}$ & 7.22 & 7.41 & $7.32^{d}$ \\
\hline$F_{5}$ & 28.40 & 30.50 & $29.45^{c}$ & 7.39 & 7.54 & $7.47^{\mathrm{c}}$ \\
\hline Mean & $29.06^{b}$ & $31.58^{\mathrm{a}}$ & & $7.43^{b}$ & $7.76^{\mathrm{a}}$ & \\
\hline & $\mathrm{SEm} \pm$ & $\mathrm{CD}$ at $5 \%$ & & $\mathrm{SEm} \pm$ & $\mathrm{CD}$ at $5 \%$ & \\
\hline Fertilizers(F) & 0.47 & 1.38 & & 0.04 & 0.12 & \\
\hline Varieties(V) & 0.29 & 0.87 & & 0.03 & 0.08 & \\
\hline$(\mathrm{V} \times \mathbf{F})$ & 0.66 & 1.95 & & 0.06 & 0.17 & \\
\hline
\end{tabular}


The highest number of umbellate per umbel was due to more number of umbels per plant as compared to rest of the fertilizer level treatments. Similar results were also reported by Tripathi et al., (2013), Mounika et al., (2018) in coriander.

\section{References}

Bhuiyan, M.N.I, Begum, J., Sultana, M. 2009. Chemical composition of leaf and seed essential oil of Coriandrum sativum L. from Bangladesh. Bangladesh Journal of Pharmacology. 4:150-153.

Choudhary, G.R., and Jat, N.L. 2004. Response of coriander (Coriandrum sativum) to inorganic nitrogen, farm yard biofertilizer. Indian Journal Agriculture Sciences78: 761-763.

Hnamte, V., Chatterjee, R. and Tania, C. 2013. Growth, Flowering, Fruit Setting and Maturity Behaviour of Coriander (Coriandrum sativum L.) with organics including biofertilizers and inorganics. The Bioscan. 8(3): 791-793.

Maheshwari, S.K., Gangreede, S.K. and Trived, K.C. 1991. Comparative responses of palmarosa to Azotobacter and nitrogen under rainfed and irrigated swards. Indian Perf. 35(2): 108-111.

Migahed, H.A., Ahmed, A.E. and Abdel Ghany, B.F. 2004. Effect of different bacterial strains as biofertilizer agents on growth, production and oil of Apiumgraveolens under calcareous soil. Arab Universities Journal of Agriculture Sciences. 12(2): 511-525.

Mirchandani, T.B. and Mirchandani, R. 2005. For balanced specialty nutrition in $\mathrm{N}$. Ram (ed.) The Hindu Survey of the Indian agriculture, Chennai 202- 205.

Mounika, Y., Thanuja Sivaram, G., Syam Sundar Reddy, P. and Ramaiah, M. 2018.
Influence of Biofertilizers and Micronutrients on Growth, Seed Yield and Quality of Coriander (Coriandrum sativum L.) Cv. Sadhana. International Journal of Current Microbiology and Applied Sciences. 7(01): 2099-2107.

Nagar, R.K., Meena, B.S. and Dadheech, R.C. 2009. Effect of Weed and Nutrient Management on Growth, Yield and Quality of Coriander (Coriandrum sativum L.). Indian Journal Weed Science. 41(4): 183-188.

National Horticulture board. 2016. National Horticulture Database. Ministry of Agriculture, Govt. of India, Guargon, India. (www.nhb.gov.in/area-pro/ horst_galance.)

Panse, V.G. and Sukhtme, P.V.1985. Stastical methods for agricultural workers. Indian council of Agricultural Research New Delhi. 87-89.

Priyadarshini, J., Panda, C.M. and Sethi, D. 2017. Effect of Integrated nutrient management Practices on Yield, Yield Attributes and Economics of Coriander (Coriandrum sativum L.). International Journal of Current Microbiology and Applied Sciences. 6(5): 1306-1312.

Sahu, R.L., Sahu, H. and Kumar, S. 2014. Effect of application of inorganic fertilizers and biofertilizers on growth components and yield traits of coriander (Coriandrum sativum L.). International Journal of Agricultural Sciences. 10(1): 433-436.

Tripathi, M.L., Singh, H. and Chouhan, S.V.S. 2013. Response of Coriander (Coriandrum sativum L.) to Integrated Nutrient Management. Technofame- A Journal of Multidisciplinary Advance Research. 2(2): 43- 46.

\section{How to cite this article:}

Suman, P., D. Lakshminarayana, P. Prasanth and Saida Naik, D. 2018. Effect of Integrated Nutrient Management on Growth Parameters of Coriander (Coriandrum sativum L.) Cultivars under Telangana Conditions. Int.J.Curr.Microbiol.App.Sci. 7(11): 2871-2877. doi: https://doi.org/10.20546/ijcmas.2018.711.330 